\title{
Delitos da testemunha
}

\section{(Parecer)}

\section{Basileu Garcia}

1 - São os seguintes os termos da consulta :

M. promoveu, perante a Terceira Junta de Conciliação e Julgamento de São Paulo, um processo de reclamação contra determinada empresa comercial. Depondo no feito como testemunha do reclamante, $V$. atribuiu falsamente a I., um dos diretores da sociedade, fato que a lei define como crime. Praticou V. o delito de calúnia? Ou ocorreu, na espécie, delito diferente, - o de testemunho falso? $\mathrm{O}$ acontecimento verificou-se ao tempo da vigência da Consolidação das Leis Penais.

A consulta veiu acompanhada de cópia de um acórdão do E. Tribunal de Apelação, que apreciou o caso. I. ofereceu queixa-crime contra $\mathrm{V}$. pelo delito de calúnia, obtendo a sua condenação, em primeira instância. Tendo havido apelação do querelado, o E. Tribunal, por dois votos contra um, reformou a sentença, para anular o processo, entendendo que $V$. só poderia ser responsabilizado como testemunha, "ficando a cargo do interessado provar a falsidade da afirmativa".

2 - Passo a responder.

A hipótese do delito de denunciação caluniosa está excluida. 0 art. 264 da Consolidação das Leis Penais exigia, na configuração dessa modalidade delituosa, fosse a falsa imputação feita em queixa ou denúncia. Resta-nos considerar 
se o fato constitue calúnia ou falso testemunho. Ou se constitue um e outro delitos.

Comete, sem dúvida, calúnia, quem a outrem falsamente atribue, mesmo ao prestar um depoimento, a prática de um crime, preciso e determinado. A legislação não outorga imunidades à testemunha: nem a antiga, nem a vigente.

O delito de falso testemunho não é, cumpre acrescentar, o único que pode cometer a pessoa chamada a esclarecer a Justiça. Outras várias formas delituosas são possiveis no depoimento, quer seja falso, quer seja verdadeiro.

Assim, o delito de violação de segredo profissional. A divulgação abusiva do segredo, a que a testemunha esteja vinculada, constituirá crime, ainda que não ocorra inverdade.

O depoimento, verídico ou mendaz, pode ser maliciosamente utilizado pela testemunha para constranger alguem à prestação de indevida vantagem econômica, integrandose, dest'arte, o delito de extorsão. E' bem de ver que, feita a prova de ter sido o depoimento empregado pela testemunha como expediente para intimidar, operando a vis compulsiva, não se livraria o depoente, com a só invocação de tal qualidade, das sanções penais estabelecidas para o delito contra o patrimônio.

Os crimes de falso testemunho e suborno (hoje, corrupção, ativa ou passiva) podem apresentar-se reunidos, formando-se um concurso material.

Suponha-se, ainda, que, depondo perante o juri, uma testemunha se abalançasse, nos termos do art. 287 do Código Penal vigente, à apologia do crime, fazendo, verbi gratia, o elogio do latrocínio como meio de luta pela subsistência; ou que escarnecesse dos julgadores, das autoridades presentes, insultando-as, desacatando-as; ou que falsamente atribuisse ao magistrado ou ao promotor a prática de um crime. Ninguem sustentaria que a testemunha, pela circunstância de o ser, estivesse a coberto de pena por esses atos. $\mathrm{E}$ isso independentemente de processo por falso 
testemunho, que poderia ser instaurado ou não, conforme as circunstâncias.

O testemunho falso e a denunciação caluniosa - deduz-se claramente do novo Código - podem relacionar-se. Esse estatuto ampliou bastante o âmbito da figura de denunciação caluniosa, ao definí-la, no art. 339, sem a referência à queixa ou denúncia, requisito a que se atinha o Código de 1890. Pratica denunciação caluniosa quem dá causa à instauração de investigação policial ou de processo judicial contra alguem, imputando-lhe crime de que o sabe inocente. Pode o agente fazê-lo em depoimento. Será, até, uma das maneiras mais seguras de causar a instauração de inquérito ou de processo judicial contra a pessoa: visada. Porquanto, nos termos do art. 66 da Lei de Contravenções, a autoridade presente ao depoimento é obrigada a agir, devendo transmitir à autoridade competente o conhecimento da acusação que lhe é trazida, se concernente a crime de ação pública.

3 - Incontestavel como é, no vigente direito positivo brasileiro, o concurso de falso testemunho e denunciação caluniosa, tal solução deve ser invocada para o caso em apreço, por diversas razões. Em princípio, o atual direito representa, na interpretação do anterior, o sentir dominante, que se tornou vitorioso. $\mathbb{E}$ é intuitivamente justo seja alcançado, não só pelas penas do testemunho falso, como pelas que são reservadas à denunciação caluniosa, quem, prestando depoimento, não uma, e sim duas vezes, prejudica a ação da Justiça: ao adulterar a vendade, concorrendo para errado julgamento do processo em que se dá $n$ depoimento; e ao originar, viciosamente, nova ação, de natureza penal, em que se perseguirá criminalmente pessoa sem culpa. Por último, atente-se a que a denunciação caluniosa é exatamente uma forma qualificada de calúnia, transplantada para diverso capítulo do Código Penal. O que de uma se diga tem, em regra, cabimento à outra. No caso vertente, como ficou acentuado, a falsa imputação não possuiria, mesmo, for- 
ça legal para ultrapassar os contornos da figura de calúnia e constituir denunciação caluniosa.

4 - Ao invés da exclusão de uma fórma delituosa pela outra, deveria antolhar-se no julgamento da causa a possibilidade do concurso de delitos. Competiria indagar sé o ato de V. permitia a acusação de ter infringido mais de um dispositivo da lei penal. A resposta seria, seguramente, afirmativa.

Sem incongruência alguma, V. poderia ser processado por falso testemunho e calúnia. O testemunho falaz, portador de acusação concientemente falsa de um crime, é fato que incide em duas diferentes disposições repressivas, consubstanciando, portanto, um concurso de delitos. Se os dois delitos ofendessem bem jurídico da mesma natureza, a afirmação ainda não seria inexata. E' comum o concúrso de infrações enquadradas no mesmo capítulo do Código Penal. Quando, porem, como aquí acontece, se apura a existência de lesão em bens diferentes, ainda mais incontestavel é a possibilidade de concurso. Na calúnia, em nosso direito, entende-se como bem jurídico ofendido a honra do cidadão; no falso testemunho, - a fé pública, perante o Código de 1890, a administração da justiça, no Código atual.

Se material ou formal seria o concurso no caso objeto da consulta, é questão dependente da análise do elemento subjetivo. Desde Carrara (Programa, § 167), como recorda Florian (Trat. de Dir. Pen., parte geral, 1934, p. 729), vem sendo assinalada a supremacia do animus na fixação do critério distintivo das duas formas de concurso, em havendo unidade de fato: "Quando exista pluralidade de fins criminosos, ainda que o fato subjetivamente considerado seja único, os vários delitos devem ser apreciados segundo as normas do concurso material", acentua o professor positivista de Turim. E, linhas adiante, falando especialmente do concurso material (p. 733): "O que separa, pois, segundo a doutrina presentemente mais aceita na Itália, essa espécie de concurso da forma precedente (concurso 
formal) é, não a pluralidade dos fatos, mas sim a pluralidade de fins, isto é, o elemento subjetivo".

$E^{\prime}$ muita vez dificil essa indagação, sempre exigida em tal problema pelo nosso direito penal, no passado e no presente. Mas como a admissão da qualidade formal do concurso representa um benefício para o acusado, que se livra da acumulação das penas, para sofrer só uma, ainda que majorada, é natural a benigna preferência pelo concurso formal, quando surja dúvida. Nem todos os casos de concurso formal se mostram com a nitidez do clássico exemplo lembrado por Battaglini (Dir. Pen., teorie generali, Belonha, 1937, p. 279) : o das relações sexuais com mulher casada, parente do sujeito ativo, praticadas com escândalo público, fato que, originário de um só escopo, repercutiria em três dispositivos criminais, nos códigos que punem o incesto.

A meu ver, o concurso de falso testemunho e calúnia será formal, se a falsidade do testemunho residir exclusivamente no ponto em que se corporifique a calúnia, porque é de crer, então, que o objetivo do agente, ao adulterar a verdade, seja apenas o de caluniar.

5 - Tal questão, porem, é meramente incidente, por ser alusiva à aplicação da pena. O que fundamentalmente interessa é averiguar se o processo poderia ser instaurado pelo delito de calúnia, alem de o poder ser, como entendeu o E. Tribunal, pelo falso testemunho. Resolvido que o processo pela calúnia era possivel, fosse ou não cabivel o referente ao falso testemunho, estaria certa a posição de I. ao oferecer queixa contra V., tal qual o fez, isto é, só pela calúnia. Isso pelas razões seguintes, cada uma das quais suficiente:

a) Sendo vítima de uma calúnia, I. não seria obrigado a queixar-se de outro crime, alem desse, mesmo que estivesse convicto de haver-se verificado tambem o outro. Vítima que seja de duas infrações à lei penal, o particular é senhor de circunscrever a uma só a sua iniciativa proces- 
sual. Poderia o Ministério Público, como litisconsorte ativo, aditar a queixa para que o processo abrangesse tambem a outra infração, de ação pública.

b) Mesmo que o Ministério Público não tomasse essa providência, seria perfeitamente regular a ação penal só pela calúnia, podendo, separadamente, vir a ser instaurado ou não o processo por falso testemunho e operar-se afinal a unificação das penas na fase de execução das sentenças penais, se, sendo dois os processos, em ambos houvesse condenação.

c) Ainda: juridicamente exata a posição de I. como queixoso de calúnia, seria, porem, de duvidosa legitimidade a sua atitude como querelante em processo por falso testemunho. Vítima de uma calúnia, ele o era, incontestavelmente, e a calúnia é delito de ação exclusivamente privada. Quanto ao falso testemunho, ter-se-ia de levar em conta que I., no processo em que foi prestado o depoimento em questão, não era autor nem réu. Era terceiro, não obstante fosse um dos diretores da empresa demandada. Para querelar, deveria apresentar-se, incontroversamente, com a qualidade de sujeito passivo do crime de testemunho falso, qualidade que não the poderia ser seguramente atribuida.

d) Finalmente: dentre as duas modalidades criminosas em discussão, a tipicidade do fato perante o preceito definidor da calúnia era a que mais se impunha, no procedimento de V. Tal procedimento reunia todos os elementos da definição legal de calúnia. Doutro lado, no tocante ao falso testemunho, a falsa imputação de crime feita contra I. constituia uma passagem accessória do depoimento. $O$ falso testemunho deve ser habil para induzir a erro a Justiça no processo em que é prestado. A não instauração da ação penal por falso testemunho, mesmo em aditamento do Ministério Público à queixa oferecida em virtude da calúnia, explicar-se-ia pelo entendimento de que a alteração da verdade não seria concernente às circunstâncias essenciais do fato submetido ao exame judicial. Desde os práticos se tem ensinado que o falso testemunho se integra "quando testis 
falsum deposuit circa factum principale vel qualitates substantiales" (Julius Clarus). "A mentira de uma testemunha sobre circunstância accessória do fato ou sobre a moralidade desse fato - professam Chauvead e HÉlie - não basta para desviar a marcha da Justiça". (Théorie du Code Pénal, vol. 3., p. 283).

6 - O falso testemunho e a calúnia, no regime da Consolidação das Leis Penais, como hoje o falso testemunho e a denunciação caluniosa, não representam modalidades inconciliaveis, que se repilam, nem inaptas a ser distinguidas na mesma ação; nem são delitos que, reunidos, deem nascimento a uma forma sui generis (delito complexo), como acontece com o furto mediante lesão à pessoa (ou morte), entidades que, juntas, constituem o roubo, ou o latrocínio.

Não redundando um dos delitos na exclusão necessária do outro, seria somente questão de prova a apuração de se terem verificado, no caso concreto, ambos ou um só. E, por conseguinte, não deveria ser evitada a discussão da prova, para concluir-se não haver lugar, em tese, para ser $\mathrm{V}$. acusado de calúnia por estar sujeito à acusação de falso testemunho.

7 - Em sua monografia sobre os crimes contra a administração da justiça, na Enciclopédia de PESSINA, D'ANToNio prevê uma hipótese muito semelhante à que ora se estuda: "Ás vezes, alvitra, a testemunha, para dar visos de verdade aos seus ditos, acusa outrem do delito pelo qual se procede. Penso que deveria responder por falso testemunho na causa em que depôs e pela calúnia, com as normas do concurso. Para mim, é fora de controvérsia que existe o primeiro delito, porquanto o agente, embora conhecendo a verdade relativamente ao delito e ao seu autor, depõe falsamente; e existe o segundo, visto que inculpa daquele delito a quem sabe ser inocente". (Vol. 7.॰, p. 721).

O caso que o presente parecer focaliza é mais característico do que o figurado pelo eminente criminalista. D'AN- 
TONIo supõe uma testemunha a ser inquirida sobre determinado crime e sua autoria, e as respostas mendazes que forneça devem importar-lhe responsabilidade por dois delitos distintos, a despeito da íntima ligação existente, na hipótese, entre a materialidade do falso testemunho e da calúnia. V., entretanto, ao imputar falsamente a I. um crime, depunha em processo de natureza civil, no qual não se cogitava de apurar nenhum crime. Não tinha de responder a perguntas especiais sobre o ato delituoso que atribuiu a $\mathbf{I}$.

Entretanto, o citado monografista não hesita em identificar um concurso de delitos na situação exemplificada, porque - argumenta - dois momentos se realçam na conduta da testemunha. Ela pode preferir, depondo em detrimento de verdade, silenciar ou negar os fatos sobre os quais é interrogada. "Quando, porem, não se limita a isso, mas vai muito alem, e declara que outro é o autor do delito, pratica um segundo fato, diverso e independente do primeiro. Compreendendo-se na sua narrativa um depoimento falso e uma inculpação ao inocente, é responsavel por um e pela outra, conjuntamente. Em outras palavras: o falso testemunho não equivale à calúnia: aquele pode existir sem esta; ajuntar a segunda ao primeiro é cometer outro delito".

Tenha-se presente que a expressão calúnia, usada nesse comentário consoante a técnica do direito italiano, significava a falsa imputação de um crime perante a Justiça, coincidindo com a denunciação caluniosa do nosso atual Código e com a calúnia do Código de 1890 , quando a acusação fosse feita sem queixa criminal, propriamente dita, ou denúncia.

8 - O venerando acórdão, na aplicação do dispoṣitivo referente à calúnia, figurou acrescida à lei uma cláusula, como se o legislador houvesse estipulado ser punivel a falsa imputação a alguem de fato definido como crime, contanto que a imputação não seja feita num depoimento.

Mas assim não estabeleceu a lei. A suposta imunidade, levada a todas as suas naturais consequências, obrigaria lo- 
gicamente a declarar impuniveis as várias infrações que apontámos como exemplos (n..$^{\circ}$ ).

Contestando essa pretendida imunidade, sintetizo a demonstração na resposta à seguinte questão:

O fato de depor é justa causa para caluniar?

A influência de justa causa é liberatória da responsabilidade em variadas situações, a propósito de diversas figuras delituosas. A justa causa é passivel de ser reduzida, geralmente, a uma das fórmulas expressas para a exclusão da injuridicidade na parte geral dos códigos penais (causas justificativas). Ás veses, todavia, quanto a determinadas modalidades criminosas, o legislador emprega palavras que conferem ao magistrado certo arbítrio no admitir justa causa sem os rigores extremos das justificativas. Assim procede empregando na definição de certos delitos expressões como estas :"sem justa causa", "indevidamente", "abusivamente". Feita essa ressalva, o procedimento que reunir todos os elementos do tipo legal de delito não pode deixar de ser penalmente reprimido, supostas naturalmente no agente as condições psíquicas requeridas pela imputabilidade.

Ora, o delito de calúnia, nem sob a letra do Código antigo, nem no vigente, se amolda à intercorrência de justa causa, que fosse consentida pela respectiva definição legal. Com tal delito não se harmonizam as causas justificativas da parte geral do Código. Sendo a calúnia a intencional imputação falsa de um crime; sendo um ato de remarcado dolo, em que o elemento subjetivo consiste precisamente na conciência da falsidade da imputação, não se poderia conceber fosse-lhe aplicada uma causa justificativa. E sem causa justificativa de ordem geral, que apoio legal teria a pretendida imunidade da testemunha, quando é certo que ao definir a calúnia o legislador não conferiu ao juiz poderes para reconhecer justa causa latamente considerada?

Observe-se, ainda, que se a lei concedesse à apreciação do delito de calúnia a admissibilidade de justa causa, o que de modo algum fez, essa tarefa teria de ser realizada 
através da discussão do mérito, o que evidencia que a queixa não poderia ser liminarmente repelida.

Tudo quanto, aliás, se possa imaginar para sustentáculo da injurídica imunidade não passaria de circunstâncias que precisariam ser demonstradas pela defesa do querelado e que seriam, ou não, reconhecidas no exame das provas. Não é possivel presumir, aprioristicamente, que toda afirmativa de uma testemunha deixe de revestir-se de espontaneidade e que todas as suas declarações promanem de sugestões do interrogatório judicial. E mesmo que tivesse havido um interrogatório sugestivo, o que cumpriria demonstrar, ainda assim poderia acontecer que o dolo se revelasse plenamente. No setor do elemento subjetivo, dever-se-ia apurar se a testemunha, ao imputar o crime, estava conciente de perpetrar uma falsidade. Admitamos que o exame das provas conduzisse a essa conclusão. Como justificar, então, a pretendida imunidade?

Impunha-se, pois, na causa, a aceitação da queixa, para o seu julgamento de meritis.

Salvo melhor juizo, é o meu parecer. 